\title{
O Fundamentalismo Cristão e ascensão da Direita Cristã nos Estados Unidos através da obra "Jerry Falwell: uma autobiografia"
}

Alexandre Guilherme da Cruz Alves Júnior ${ }^{1}$

Resumo: Este artigo analisa a ascensão da Direita Cristã no cenário político dos Estados Unidos, no final dos anos 1970, através da obra Jerry Falwell: uma autobiografia, de modo a compreender, a partir da narrativa autorreferencial do pastor fundamentalista cristão, a complexidade de fatores que fomentou a aliança política entre importantes figuras religiosas conservadoras e o partido Republicano.

Palavras-chave: Estados Unidos; Direita Cristã; Jerry Falwell.

\section{Christian Fundamentalism and the rise of the Christian Right in the United States in "Jerry Falwell: An Autobiography"}

\begin{abstract}
This article analyzes the rise of the Christian Right in the United States political scene, in the late 1970s, through the book Jerry Falwell: an autobiography, in order to understand, from the self referential narrative of the Christian fundamentalist pastor, the complexity of factors that fostered the political alliance between important conservative religious figures and the GOP.
\end{abstract}

Keywords: United States; Christian Right; Jerry Falwell.

Artigo recebido em: 27/11/2017

Artigo aprovado para publicação em: 14/03/2018

\section{Apresentação}

Em 15 de maio de 2007, Jerry Falwell, pastor Batista e fundamentalista cristão, foi encontrado morto, aos 73 anos, em seu escritório na Universidade Liberty, localizada na cidade de Lynchburg, Virgínia. Uma parada cardíaca calou uma das vozes mais proeminentes do cenário político e religioso conservador dos Estados Unidos durante mais de 40 anos.

Rapidamente, a notícia de sua morte ganhou as primeiras páginas da imprensa local e internacional. Uma multiplicidade de vozes veio a público repercutir o

\footnotetext{
${ }^{1}$ Doutor em História. Professor de História da América na Universidade Federal do Amapá/Campus Binacional do Oiapoque, Brasil. Docente permanente do Mestrado em Ensino de História (PROFHIST) da Unifap. A pesquisa contou com o financiamento da CAPES. Contato: alexandrecruzunifap@gmail.com
}

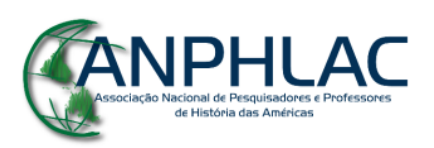

Revista Eletrônica da ANPHLAC, ISSN 1679-1061, №. 24, p. 253-280, Jan./Jun., 2018.

http://revista.anphlac.org.br 
significado e o legado desse personagem para a sociedade norte-americana ${ }^{2}$, compondo um conjunto de opiniões contraditórias; por vezes lamentando profundamente o falecimento do pastor, considerado um defensor fervoroso e obstinado dos intrínsecos valores cristãos dos Estados Unidos e, por outras vezes, sublinhando um lado considerado preconceituoso e hipócrita do mesmo homem.

O jornalista Max Blumenthal, crítico do radicalismo religioso cristão, publicou no periódico The Nation, um dia após a morte de Falwell, o artigo intitulado: Agent of Intolerance, descrevendo os eventos mais controversos de sua vida pública. Blumenthal recuperou algumas das últimas declarações polêmicas de Falwell no cenário político e social norte-americano: como acusar o personagem Tinky Winky, dos Teletubbies, de ser homossexual em 1999 e, após os atentados terroristas em 2001 nos Estados Unidos, declarar que vários grupos progressistas no interior do país haviam ajudado, de certa forma, os atentados a ocorrerem.

Esta última declaração polêmica foi dada ao também pastor televangelista, Pat Robertson, durante o programa de televisão, The $700 \mathrm{Club}$, dias após os atentados terroristas de 11 de setembro de 2001. Falwell, defendendo uma nação orientada pelas leis do cristianismo, acusou os ateus, os defensores do aborto, as feministas, os gays e lésbicas e a organização People for the American Way de enfraquecerem espiritualmente o país, posto que, ao buscarem secularizar os Estados Unidos, tinham afastado a proteção de Deus, abrindo espaço para atentados terroristas.

De todo modo, torna-se evidente que Jerry Falwell despertou admiração, ódio, paixão e fúria, buscando o consenso em torno de suas ideias, ao mesmo tempo em que estimulava o dissenso na sociedade norte-americana.

O presente trabalho tem como objetivo compreender a trajetória do líder religioso, que se tornou mais tarde referência política fundamental para a consolidação da Direita Cristã nos Estados Unidos, considerando sua autobiografia publicada em 1997, Falwell: An Autobiography, como fonte principal de análise.

Como afirma Jaume Aurell (2014, p. 340),

\footnotetext{
${ }^{2}$ Embora estejamos cientes da imprecisão conceitual, uma vez que Canadá e México situam-se na América no Norte, optamos pelo uso do termo "norte-americano" para designar a população dos Estados Unidos devido ao seu uso e maior familiaridade pelos leitores brasileiros. Vale ressaltar que na historiografia podemos encontrar autores que optam por utilizar o termo "estadunidense", ao até mesmo "americano", devido ao modo como a população nascida nos Estados Unidos se autodenomina.
}

\section{GANPHLAC}


a biografia enquanto relato é o resultado de memórias (ou mesmo esquecimentos) coletivas, individuais e sociais, constantemente negociadas e processadas, com vínculos com mitos, saberes, fazeres e tradições que se corporificam a partir de relações particulares com o tempo e o espaço, que não são simplesmente atos de resgate, mas de reconstrução do passado a partir de referenciais atuais. Dentro desse universo, as situações nas quais narrador e personagem são a mesma pessoa caracterizam a expressão literária da autobiografia, cuja manifestação entre historiadores é também chamada de ego-história, situação na qual a identidade autor-narrador rompe com as instâncias dicotômicas que, mesmo com ressalvas, caracterizam os gêneros ficcionais.

Faz-se necessário, portanto, considerar a obra Falwell: An Autobiography, tanto do ponto de vista do contexto de sua produção quanto das operações de reconstrução do passado, identificáveis em suas linhas; contrastando-as, para tal, com outros escritos de Jerry Falwell, produzidos em contextos distintos.

Neste sentido, entendemos que a análise da narrativa sobre sua trajetória de vida encontrada na obra, sua atuação frente ao grupo político Moral Majority, e influência no interior do partido Republicano, pode nos revelar como o fundamentalismo cristão e o conservadorismo norte-americano sofreram influências da conjuntura social, política e econômica norte-americana entre os anos 1950 e 1970, reafirmando cânones históricos, mas, também, empreendendo mudanças no método e no conteúdo de seus projetos.

\section{Os primeiros anos e o encontro com Deus}

Jerry Falwell nasceu em 11 de agosto de 1933, na cidade de Lynchburg, Virgínia. Seu pai, Carey Falwell, um Democrata fervoroso, era um importante empresário local, atuando em diversas áreas, como transporte público, bares e construções. Carey Falwell costumava se utilizar de seus ônibus para organizar caravanas em que incentivava negros e brancos pobres a fazerem o registro eleitoral.

Por outro lado, como aponta Jerry Falwell em sua autobiografia, seu pai também apresentava comportamentos bastante controversos.

Quando eu tinha dez anos, lembro-me de visitar meu pai em seu escritório no dia do pagamento. Papai estava sentado à sua mesa distribuindo cheques para seus empregados. Seu hábito de beber tinha aumentado imensuravelmente nesses últimos anos. No momento em que eu entrei na escola, ele estava bebendo uma dúzia de cervejas por dia e tragando uma dose ou mais de uísque além delas. Ele geralmente escondia a bebida e raramente mostrava o menor sinal de estar bêbado. Mas quando tinha bebido muito [...] era perigoso cruzar com ele. (FALWELL, 1997, p. 20)

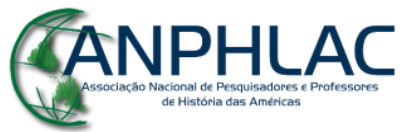

Revista Eletrônica da ANPHLAC, ISSN 1679-1061, №. 24, p. 253-280, Jan./Jun., 2018.

http://revista.anphlac.org.br 
De fato, os problemas de seu pai com a bebida orientaram uma das primeiras bandeiras sociais de Falwell anos mais tarde, a luta contra o alcoolismo. Embora tenha representado a imagem de seu pai como um alcoólatra geralmente pouco agressivo, Falwell narrou algumas passagens em sua autobiografia que indicam justamente o contrário. Muitas vezes, quando contrariado por algum empregado, Carey Falwell sacava seu revólver e o usava como ameaça.

Referências à figura paterna estiveram presentes durante toda a vida pública de Falwell, servindo sempre como uma espécie de espelho invertido, um exemplo negativo que logrou superar através da vida religiosa. Por outro lado, sua figura materna, Helen Beasley, era descrita por Falwell de maneira oposta. Segundo Falwell, sua mãe havia se convertido ao cristianismo ainda criança: "Ela aprendeu a ler a Bíblia e a orar ainda na pré-adolescência e nunca mais parou de ler e orar até o dia em que morreu" (FALWELL, 1997, p. 57).

Embora existam discordâncias sobre o exato momento da conversão de Helen Beasley, posto que para alguns biógrafos, sua conversão se daria anos após Jerry Falwell ter se tornado pastor, fato é que a figura materna se tornou, na narrativa autobiográfica de Falwell, uma conexão, ainda que silenciosa, com o cristianismo e, mais especificamente, com a Igreja Batista, durante sua adolescência pouco religiosa. $O$ jovem Falwell preocupava-se em praticar esportes, passando a liderar um grupo de amigos conhecidos como a Wall Gang. Em suas memórias, Falwell buscou minimizar sua liderança no grupo, afirmando que foi eleito o líder nominal da gangue apenas por ser o único a ter carro. (FALWELL, 1997)

Como afirma Winters (2012, p. 23), "Falwell insistiu mais tarde que a violência [atribuída aos membros da gangue] nunca resultou em algo a mais do que lábios cortados, ossos quebrados ocasionalmente, e pequenas propriedades danificadas." Em sua autobiografia, Falwell fez questão de caracterizar a Wall Gang como um grupo de adolescentes rebeldes, mas que não se comportava como uma gangue étnica (um jovem negro teria sido aceito no grupo posteriormente) e, além do álcool muito raramente consumido, não havia drogas envolvidas.

\section{GANPHLAC}


Durante os seus anos no Brookeville High School, Falwell destacou-se em matemática e ciências. Participou de inúmeras atividades extracurriculares, atuando como editor do jornal da escola e como capitão dos times de baseball e basquete.

Em 1948, mesmo ano da morte de seu pai em decorrência do alcoolismo, Jerry Falwell concluiu a escola. Como fica evidente em sua autobiografia, os últimos anos de Carey Falwell marcaram profundamente a vida do filho. No contexto da publicação de suas memórias, Falwell lançou um olhar religioso para rememorar as causas da morte de seu pai. "Lembrando" como um pastor, associou o alcoolismo e a destruição física de Carey Falwell à sua distância de Deus. "O que tinha sido um homem forte e orgulhoso, havia se tornado uma vítima de seus pecados imperdoáveis. Deus amou o meu pai, mas meu pai não acreditava em Deus. Pouco a pouco, o Inimigo venceu” (FALWELL, 1997, p. 89).

No começo dos anos 50, Jerry Falwell entrou na Universidade de Lynchburg para cursar engenharia mecânica. Embora tivesse aulas de religião, Falwell mostrava-se pouco interessado pelo tema. Não fosse o hábito de sua mãe de ouvir todas as manhãs de domingo o programa de rádio do pastor Charles Fuller, intitulado Old-Fashioned Revival Hour, a vida do jovem Falwell poderia ter seguido um caminho diferente. Na verdade, Falwell sempre demonstrou indiferença pelo programa religioso que sua mãe ouvia na rádio. Mas, como narrou em sua autobiografia, ao acordar na manhã de 20 de janeiro de 1952, algo o atentou para o programa, algo que viraria sua vida de cabeça para baixo.

\section{Convertendo-se em um Born Again}

Como aponta Hale (2011), tornar-se um born again no aspecto religioso do protestantismo norte-americano não é apenas um movimento de transformação interior radical. Uma mudança drástica de hábitos e valores. Tornar-se um born again é antes de tudo contar e recontar uma história. A história do reencontro com Jesus.

Embora Jerry Falwell tenha repetido inúmeras vezes, ao longo de sua vida pública, em sermões, programas de rádio e televisão, a história da manhã de domingo em que reencontrou Jesus, usaremos como base a versão utilizada em sua autobiografia de 1997:

\section{GANPHLAC}

Revista Eletrônica da ANPHLAC, ISSN 1679-1061, №. 24, p. 253-280, Jan./Jun., 2018.

http://revista.anphlac.org.br 
A manhã de domingo começou sem grandes eventos. Acordei cedo com o cheiro de hoecake e bacon flutuando pelas escadas em minha direção. Naqueles dias, eu me perguntava se minha mãe tinha usado um ventilador elétrico para levar aquele maravilhoso cheiro ao meu quarto nas manhãs de domingo. Era sua maneira de me fazer descer as escadas para ouvir a transmissão semanal do 'Old Fashioned Revival Hour'. Da minha cama eu podia ouvir o coral cantando 'Heavenly Sunshine' no volume máximo. [...] Finalmente, eu sucumbi ao cheiro de melaço, desci as escadas e entrei na cozinha disposto a ouvir o sermão em troca do café da manhã caseiro. Charles Fuller estava lendo um texto em seu púlpito na rádio do Auditório Municipal de Long Beach. Mamãe tinha organizado a mesa e a comida estava no lugar, então eu não perderia uma palavra. Eu brinquei com a minha mãe por estar ouvindo o sermão de Fuller naquela manhã. Eu não me lembro de seu texto, mas eu lembro que senti algo que eu nunca havia sentido antes. Tive vontade de chorar, mas eu não estava triste. Eu me senti excitado, mas não havia nada excitante na minha agenda naquele dia. Fuller foi aquecendo o seu texto, e enquanto eu estava ouvindo suas palavras, eu fui me lembrando de outras palavras faladas em outros momentos. Fuller disse: 'Você é um renascido? 'E eu me lembrei do meu companheiro de quarto na universidade me perguntando exatamente a mesma questão. [...] Eu não sabia nada sobre o Espírito Santo. Se alguém tivesse me dito que naquele dia o próprio Deus estava presente na cozinha da nossa família operando para me salvar do pecado, eu teria rido em voz alta. Mas olhando para trás, foi a Sua presença que eu estava sentindo. [...] Ele estava me chamando, mas eu não reconhecia a Sua voz. Eu me senti nervoso e animado como quando você está diante de uma forte tempestade ou naquele momento no hospital pouco antes do nascimento do seu primeiro filho." (FALWELL, 1997, p. 118)

Embora a citação seja longa, ela é fundamental para compreendermos que a história do renascimento de Jerry Falwell não é utilizada apenas para narrar o momento íntimo de sua conversão interior, mas também para evangelizar. De certa forma, não foi ele quem escolheu Deus, mas Deus quem o escolheu. Embora ele não reconhecesse a voz, Deus estava falando com ele.

Vale ressaltar também o papel desempenhado pela sua mãe no processo de conversão. Para fazê-lo sair da cama, em tempo de ouvir o sermão de Charles Fuller no rádio, Helen não poupou esforços em preparar "o melhor" café da manhã possível. Sendo assim, Falwell ratifica o papel de sua mãe como o exemplo religioso em casa e, por conseguinte, o papel das mulheres como instrumento de evangelização de suas famílias. Por último, fica evidente o tom dramático e emotivo que acompanha a história de conversão de Jerry Falwell em particular, e dos born again em geral. As metáforas utilizadas, tais como "forte tempestade" e "nascimento de um filho", evocam nas pessoas sentido de grandiosidade e emoção. Como afirma Hale (2011), a narrativa do momento da conversão, do renascimento, baseia-se em uma teatralização constante.

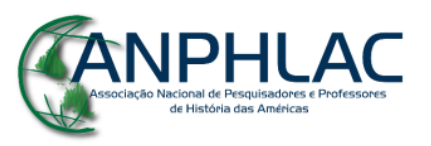

Revista Eletrônica da ANPHLAC, ISSN 1679-1061, №. 24, p. 253-280, Jan./Jun., 2018.

http://revista.anphlac.org.br 
O conceito de born again apropriado neste trabalho se refere à definição dada pelos setores conservadores das denominações protestantes norte-americanas na segunda metade do século XX. ${ }^{3}$

$\mathrm{Na}$ concepção dos fundamentalistas cristãos norte-americanos, o termo "born again" é inspirado em diferentes passagens bíblicas. O reconhecimento do pecado torna-se pré-condição para qualquer possibilidade de redenção.

Porém, é no Evangelho de João que o termo born again aparece como remédio último para se livrar da vida de pecados e alcançar o reino de Deus. No trecho bíblico em que narra o momento em que o fariseu Nicodemos perguntou a Jesus como poderia alcançar a salvação eterna. Jesus respondeu-lhe "Em verdade, em verdade te digo que se alguém não nascer de novo, não pode ver o reino de Deus".

\section{$* * *$}

Naquela tarde de domingo, Falwell foi se encontrar com os amigos da Wall Gang como sempre costumava fazer em dias de folga. Entre os assuntos recorrentes discutidos entre os amigos, Falwell introduziu um tema novo, ao perguntar se algum deles conhecia alguma igreja em Lynchburg. Wilson Wright, um de seus amigos, respondeu-lhe que já tinha frequentado a Park Avenue Baptist Church, onde havia boas músicas e muitas garotas bonitas. (FALWELL, 1997)

Naquela noite, Falwell e seus amigos foram até a igreja, onde o pastor Paul Donnelson estava pregando sobre o pecado e suas consequências, pontuando vários temas parecidos com o que Falwell escutara durante o café-da-manhã pela rádio. Para Falwell, estas "coincidências" seriam a prova da ação de Deus sobre sua vida. Por outro lado, podemos entender que a questão do pecado e da regeneração são temas recorrentes na retórica de algumas denominações do protestantismo conservador norte-americano, não sendo, portanto, incomum, que estes temas apareçam de forma recorrente, atuando na construção de um moralismo bastante estreito.

Durante a pregação, vários membros da igreja foram até o altar trocar algumas palavras com o pastor. Entretanto, Falwell permaneceu sentado. "Eu estava ficando cada

\footnotetext{
${ }^{3}$ De fato, a figura do born again existe em diferentes religiões, advindo não necessariamente de uma experiência pessoal, mas muitas vezes de um ritual religioso, como por exemplo, o batizado católico.
}

\section{GANPHLAC}

Revista Eletrônica da ANPHLAC, ISSN 1679-1061, №. 24, p. 253-280, Jan./Jun., 2018. 
vez mais animado e mais nervoso. Eu sabia que algo importante estava prestes a acontecer" (FALWELL, 1997, p. 118). Um dos fiéis então convidou Falwell para ir até o altar. Este, segundo sua narrativa, ajoelhou-se diante do altar, e o pastor Paul Donnelson postou-se ao seu lado e lhe perguntou se era um pecador. Falwell respondeu que sim, e ouviu uma tréplica surpreendente: "Claro que sim! Todos nós somos pecadores!" Falwell, então, olhou para o velho senhor que o havia acompanhado ao altar, Garland Carey, e o viu sorridente, repetindo um trecho da Bíblia: "O salário do pecado é a morte [...] Mas a verdade de Deus é a vida eterna em Cristo Jesus, nosso Senhor" (FALWELL, 1997, p. 123).

No domingo seguinte, Falwell e alguns de seus amigos da Wall Gang, participaram da primeira aula bíblica. Lá também estava Macel, sua futura esposa. O interesse de Falwell por Macel foi imediato e, no culto noturno, Falwell procurou sentar-se próximo dela.

\footnotetext{
Naquela noite, na reunião de jovens, Dolores e Macel tomaram seus lugares nos pianos verticais. Destemidos, eu e Jim nos sentamos na primeira fila para ter a melhor vista possível. Nossos motivos para frequentar a igreja durante os primeiros domingos, na melhor das hipóteses, estavam misturados. [...] Mas Jack Dinsbeer realmente não estava interessado no por que tínhamos ido. Ele sabia que, após a conversão, o primeiro passo para o fiel cristão é estabelecer-se em uma igreja local e na comunhão de outros cristãos." (FALWELL, 1997, p. 133)
}

De fato, Jerry Falwell passou a participar de inúmeras atividades na igreja. Aprendeu a recitar rapidamente algumas passagens da Bíblia e passou a visitar domicílios pela região, levando a sua nova doutrina religiosa a outras pessoas. Nem sempre foram bem recebidos, havendo inclusive casos em que a polícia foi chamada. Porém, nada impediu o grupo de jovens da Park Avenue Baptist Church de continuar seu trabalho evangelizador e, assim, levar novos fiéis para a igreja.

Dedicando-se cada vez mais a vida religiosa, Falwell tornou-se amigo do pastor Donnelson, e decidiu abandonar a universidade de Lynchburg, ingressando, no final de 1952, na Baptist Bible College, de orientação fundamentalista, em Springfield, Missouri. (FALWELL, 1997).

\section{O Fundamentalismo Cristão e a Thomas Road Baptist Church}

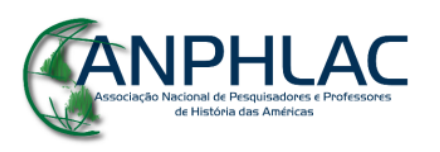

Revista Eletrônica da ANPHLAC, ISSN 1679-1061, №. 24, p. 253-280, Jan./Jun., 2018.

http://revista.anphlac.org.br 
O fundamentalismo cristão surgiu como um movimento evangélico no começo do século XX nos Estados Unidos, contrapondo-se ao que encarava como os males da sociedade moderna e, principalmente, como reação à interpretação histórico-crítica da Bíblia, empreendida por denominações evangélicas progressistas. Estas denominações abandonaram a interpretação literal dos textos sagrados, rejeitando o que classificavam como uma visão mitológica e dogmática do cristianismo.

Segundo Mardsen (1980), para compreendermos o movimento fundamentalista cristão é necessário analisá-lo a partir das transformações que a sociedade norteamericana estava experimentando no início do século XX. Em um ambiente de efervescência econômica e cultural, rápida urbanização, diversos valores modernos, como o cientificismo, o secularismo e o individualismo, expandiram-se rapidamente entre diferentes camadas da sociedade norte-americana, ricocheteando em algumas denominações mais liberais do protestantismo naquele país. Este contexto gerou uma forte reação de grupos evangélicos mais conservadores, contrários à expansão dos valores modernos, principalmente quando atrelados à interpretação da Bíblia.

Embora muitos autores identifiquem no terceiro grande despertar religioso norteamericano $^{4}$ as raízes do fundamentalismo, o termo foi cunhado apenas após a publicação, entre 1910 e 1915, de 12 volumes intitulados The Fundamentals. As obras foram financiadas por um magnata da Califórnia, Lyman Stuart, e editadas por A. C. Dixon.

The Fundamentals tinham a função de reforçar os 5 pilares básicos do cristianismo elaborados na década anterior no Seminário Presbiteriano Teológico de Princeton: a interpretação literal da Bíblia; a reafirmação da divindade de Cristo; a proclamação do nascimento virginal de Jesus; a pregação da morte e ressurreição de Jesus como garantias da redenção; e a proclamação da ressurreição da carne como certeza da segunda vinda de Cristo. As obras criticavam diretamente o Romanismo (catolicismo), o darwinismo, a teologia liberal, o socialismo, a filosofia moderna, o ateísmo, etc.

\footnotetext{
${ }^{4} \mathrm{Na}$ história dos Estados Unidos, são identificados quatro grandes despertares religiosos. Sua cronologia ainda é motivo de debates na historiografia. Entretanto, podemos datá-los, grosso modo, da seguinte maneira: $\mathrm{O} 1^{\circ}$ entre 1730 -1755; o $2^{\circ}$ entre 1790-1840; o $3^{\circ}$ entre 1850-1900; e o $4^{\circ}$ entre 1960-1980. Para alguns autores, no início do século XXI, durante as duas administrações de George W. Bush (2000-2008), os Estados Unidos teriam vivido um $5^{\circ}$ despertar religioso.
}

\section{GANPHLAC}


Como aponta Mardsen (2001), cada vez mais, os fundamentalistas cristãos se caracterizavam por um discurso de "guerra" contra a teologia liberal e contra os valores mais progressistas da sociedade norte-americana.

As disputas internas entre algumas denominações protestantes geradas pela ascensão dos fundamentalistas como um grupo de pressão, embora heterogêneo, não tardou a ocorrer na arena política. As correntes seculares na sociedade norte-americana, consideradas pelos fundamentalistas cristãos como um desvio moral da nação, tornaram-se alvo desse fervor religioso. ${ }^{5}$ Vale ainda ressaltar a grande contradição notada por Mardsen (1980) em relação aos fundamentalistas cristãos. Se por um lado desprezam os valores modernos da sociedade norte-americana, por outro, sentem uma grande necessidade de interagir com ela. $O$ que nos sugere que, embora os fundamentalistas se vejam como defensores de visões de mundo pré-modernas, são eles mesmos frutos da modernidade.

Jerry Falwell estudou e discutiu estas e outras questões durante sua estadia na Baptist Bible College. Segundo Winters (2012), a maioria dos professores era fundamentalista, e dentre as práticas pedagógicas estava a leitura de 3 capítulos da Bíblia por dia, sendo que aos domingos os capítulos aumentavam para 5. Falwell destacou-se entre os estudantes de sua turma, formando-se com honras em 1956. O jovem que resistia a frequentar Igrejas, agora tornara-se um instruído pastor fundamentalista.

Pretendendo mudar-se para a Georgia, Falwell retornou a sua terra natal para passar um tempo com a sua família e visitar algumas igrejas da região. Em Lynchburg, encontrou uma divisão na congregação na qual iniciaria sua vida religiosa. Um grupo de 35 fiéis, dentre os quais estava a família de Macel, sua futura esposa, havia abandonado a Park Avenue Baptist Church, por discordâncias com o novo pastor. Os dissenters ${ }^{6}$,

\footnotetext{
${ }^{5}$ Importante salientar que os fundamentalistas também se tornaram alvos das correntes mais progressistas e seculares da sociedade norte-americana, sendo classificados por setores da imprensa e da sociedade civil organizada como obscurantistas. Mardsen (2001) trata esses embates na década de 1920 como uma "guerra cultural".

${ }^{6}$ Vale ressaltar que, para os protestantes em geral, a palavra dissenters (dissidentes) não possui uma conotação pejorativa. Mas remonta aos primeiros dissidentes do período da reforma religiosa.
}

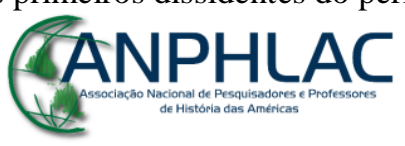

Revista Eletrônica da ANPHLAC, ISSN 1679-1061, №. 24, p. 253-280, Jan./Jun., 2018.

http://revista.anphlac.org.br 
como ficaram conhecidos, convidaram Falwell para assumir uma nova igreja batista em Lynchburg. (FALWELL, 1997)

\begin{abstract}
Eu fiquei chocado. Imediatamente eu expliquei os meus planos de começar uma igreja em Macon. Eles me pediram para reconsiderar. Então eu pensei que o mínimo que podia fazer era prometer a esses velhos amigos que eu iria orar sobre o tema. Às vezes, os cristãos usam essa pequena promessa 'Vou orar sobre isso', quando eles realmente querem dizer não, mas não têm a coragem de dizê-lo. Mas eu estava sendo sincero, e imediatamente comecei a orar sobre ajudar a começar uma segunda igreja em Lynchburg. Apenas uma semana antes eu tinha orado por orientação, e Deus havia respondido: 'Vá para Macon!'. Ou assim pensei eu. Mas quando eu orei novamente por orientação, eu senti Deus me guiando para ficar em Lynchburg [...] Ambas as portas pareciam abertas para mim. Desta vez, enquanto eu orava, Deus parecia estar deixando a decisão em minhas mãos. [...] Deus não pensa por nós. [...] Ele nos permite tomar as decisões difíceis sozinhos." (FALWELL, 1997, p. 186-7)
\end{abstract}

Este momento de dúvidas e anseios antes de aceitar a liderança da nova igreja é narrado em sua autobiografia de modo a justificar o racha que a nova igreja criou entre os batistas em Lynchburg, chegando mesmo à Bapstist Bible Fellowship (BBF) ${ }^{7}$. Anos mais tarde, Falwell diria que foi praticamente "excomungado" e impossibilitado de receber qualquer ajuda ou suporte de seus pares batistas. Este "isolamento" duraria exatos 15 anos.

Em uma interessante passagem, Falwell faz uma referência direta ao homem da fronteira norte-americano, independente, corajoso e individualista, associando-o ao espírito batista para justificar sua decisão de romper com a BBF em 1956.

\begin{abstract}
Os batistas são seres humanos como qualquer pessoa. [...] Muitas vezes, nós agimos primeiro e pensamos e oramos depois. Nossas igrejas estão cheias de homens da fronteira determinados e independentes, que não se curvam à autoridade de nenhum homem (ou de nenhuma mulher). Claro, esses espíritos independentes podem brigar e dividir, mas muitas vezes através da divisão vem o crescimento e expansão para a igreja. [...] Eu aprendi durante esses longos quinze anos que eu não precisava de uma comunidade para me guiar. Eu não precisava de um programa a seguir [...] Eu não precisava de uma sede ou de uma hierarquia para confiar. Jesus Cristo era tudo isso para mim. (FALWELL, 1997, p. 188-194. Grifos nossos)
\end{abstract}

\footnotetext{
${ }^{7}$ A Baptist Bible Fellowship, localizada em Springfield, Missouri, é uma organização composta por igrejas fundamentalistas dissidentes da World Baptist Fellowship, criada em 1950 pelo pastor J. Frank Norris.
}

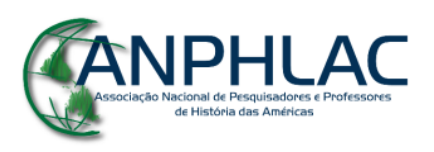

Revista Eletrônica da ANPHLAC, ISSN 1679-1061, №. 24, p. 253-280, Jan./Jun., 2018.

http://revista.anphlac.org.br 
A referência ao self-made man (o homem que se faz por conta própria), independente e resoluto, encontra forte eco na identidade nacional norte-americana, e pode ser utilizado por diferentes atores sociais (muitas vezes, em campos ideológicos opostos) para justificar ações individuais ou de rompimento com a ordem vigente. Essas apropriações comumente se afastam do significado dado originalmente por Frederick Jackson Turner ao homem do Oeste no final do século XIX, cunhado dentro de um contexto histórico específico. Não era este o caso de Jerry Falwell naquele momento, sobretudo porque ele havia se constituído pastor sob as regras e autoridade da BBF, as quais conhecia muito bem, tendo tido, inclusive, paciência tentando convencer seus superiores da possibilidade de uma segunda igreja em Lynchburg, optando pelo rompimento apenas quando se esgotaram todos os canais de diálogo.

Este fato demonstra como a figura do homem da fronteira pode ser reelaborada a partir de contextos distintos na cultura norte-americana, revelando toda a sua plasticidade na dinâmica social. ${ }^{8}$

Jerry Falwell deixou de ser porta-voz dos Dissenters para tornar-se ele mesmo um dissidente. $\mathrm{O}$ grupo iniciou então a busca por um local para fundar a nova igreja. Um antigo prédio pertencente a Donald Duck Bottling Company, localizado no extremo oeste de Lynchburg, uma região que havia crescido após a Segunda Guerra Mundial, foi o local escolhido. O preço do aluguel era acessível, 300 dólares, e o prédio possuía bastante espaço. (WINTERS, 2012). Em primeiro de julho de 1956, domingo pela manhã, a Thomas Road Baptist Church (TRBC) iniciou os seus trabalhos na nova sede. ${ }^{9}$

Rapidamente, Falwell elaborou uma estratégia agressiva para conquistar novos fiéis. Junto a alguns membros da TRBC, batia de porta em porta visitando as casas da região, sempre levando consigo uma Bíblia e um pequeno caderno onde anotava dados sobre as pessoas com as quais conversava, principalmente quantas pessoas moravam na residência, qual igreja frequentavam e, especialmente, quais os problemas pessoais os entrevistados relatavam. (WINTERS, 2012; FALWELL, 1997)

\footnotetext{
8 "O mito do Oeste atravessa toda a sociedade norte-americana de forma mobilizadora. Se é ainda uma referência, é porque o apelo ao Oeste encontra ressonância naquela sociedade. [...] O fascínio pelo Oeste mítico é tanto nos Estados Unidos, ainda nos dias de hoje, que o tema continua explorado, especialmente pelas agências de propaganda." (JUNQUEIRA, 2001, p. 61-63)

${ }^{9}$ A primeira reunião do grupo batista dissidente se deu no dia 17 de junho de 1956, no auditório da Mountain View Elementary School em Lynchburg. Esta é a data considerada como a fundação oficial da TRBC. Entretanto, na autobiografia de Jerry Falwell, a primeira reunião aparece datada do dia 21 de junho de 1956.
}

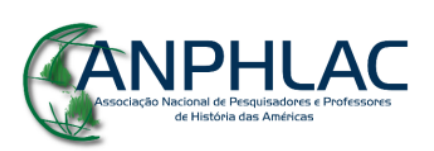

Revista Eletrônica da ANPHLAC, ISSN 1679-1061, №. 24, p. 253-280, Jan./Jun., 2018.

http://revista.anphlac.org.br 
Logo nas primeiras semanas, Falwell e alguns colaboradores confeccionaram um jornal informativo sobre as atividades semanais na TRBC. Tais jornais eram enviados pelo correio às residências visitadas nas semanas anteriores. Alguns voluntários ligavam para as residências de conhecidos, pedindo permissão para o envio do periódico semanal. (FALWELL, 1997)

Uma noite, enquanto ouvia música com Macel, Jerry Falwell lembrou-se de como havia sido tocado pela palavra de Deus ao ouvir o programa de Charles Fuller. Teve então a ideia de procurar a rádio local para alugar um horário em que pudesse proferir sermões e divulgar a agenda semanal da TRBC. ${ }^{10} \mathrm{Na}$ verdade, Jerry Falwell percebeu que na parte da manhã o rádio estava ligado na maioria das casas que visitava, e durante a noite, a televisão ganhava a atenção das famílias. (FALWELL, 2008)

A ideia original de Falwell era criar um programa semanal. Porém, ao chegar à recém inaugurada estação de rádio $W B R G$, o pastor encontrou um projeto mais audacioso. Brent Epperson, dono da estação, pretendia que sua grade contasse com um programa religioso diário na parte da manhã, com 30 minutos de duração. Falwell aceitou o desafio, e estruturou o programa Old Time Gospel Hour da seguinte forma: o horário seria das 7:00h às 7:30h (durante o verão, o programa começaria às 6:30h), e o tempo seria dividido em 20 minutos de apresentações musicais (muitas vezes Falwell utilizava canções gravadas em sua própria igreja), intercaladas com a divulgação da programação da TRBC, e de quais locais Falwell visitaria pessoalmente pelo restante da manhã. Nos 10 minutos finais, Falwell proferia um curto sermão, e convidava os ouvintes a visitarem sua igreja. (WINTERS, 2012)

Segundo Falwell, os resultados alcançados pelo programa de rádio superaram suas expectativas, fazendo-o sonhar com um programa de televisão.

Em dezembro de 1956, eu decidi que era hora de agir. Numa manhã de
segunda-feira eu dirigi até o pequeno estúdio e escritório da nossa filial da
ABC. [...] A estação me ofereceu meia hora semanal por 90 dólares. Eu
assinei o contrato imediatamente. [...] Posteriormente, na tarde de domingo,
Macel, Bill e eu chegamos ao estúdio sem absolutamente nenhuma instrução
sobre o que deveríamos fazer. Às $17: 30$ h uma luz vermelha começou a piscar
na porta do estúdio, e o cameraman/diretor fez sinal para iniciar o programa.

10 A partir das décadas de 1920 e 1930, o rádio passou a ser utilizado por importantes figuras do protestantismo norte-americano como meio de evangelização. Além de Charles Fuller, podemos citar ainda Aimee Semple McPherson, Paul Rader e Billy Graham (este último, nos anos 1940) como pioneiros em fazer pregações e adaptar suas mensagens para o novo veículo.

\section{GANPHLAC}

Revista Eletrônica da ANPHLAC, ISSN 1679-1061, №. 24, p. 253-280, Jan./Jun., 2018.

http://revista.anphlac.org.br 
'Olá' eu disse, olhando para Macel e Bill esperando apoio, 'Meu nome é Jerry Falwell. Eu sou o pastor da Igreja Batista Thomas Road. (FALWELL, 1997, 223-225)

A partir desse momento, Jerry Falwell entrava para o seleto grupo dos televangelistas.

No primeiro ano de atividades, a TRBC viu crescer exponencialmente o número de fiéis, alcançando em 1957 um total de 500. Poucos sermões proferidos por Falwell em seus primeiros anos foram registrados, sendo que destes, a ampla maioria se relacionava com temas como conversão, métodos de oração, interpretação de passagens bíblicas, etc. Porém, um polêmico sermão proferido em 1958 foi o escolhido por Falwell, na época, para ser transcrito e enviado pelo correio ao público de seu programa de televisão. O sermão intitulado Segregation or Integration, Which? fazia referência direta à decisão da Suprema Corte, em 1954, no caso Brown vs Board of Education ${ }^{11}$, que considerou inconstitucional a segregação racial nas escolas públicas.

Segundo o pastor, a decisão de 1954 havia criado o caos social e estimulado tensões raciais até então inexistentes nos Estados Unidos. Este discurso alinhava-se com as vozes políticas analisadas acima. Entretanto, Falwell encontrou na Bíblia a justificativa para a manutenção da segregação nas escolas públicas. Mais do que considerar uma intervenção indevida do judiciário no campo legislativo, Falwell considerou que houve uma intervenção do judiciário nos preceitos da Bíblia, o que, para um pastor fundamentalista, era ainda pior.

Na segunda metade do sermão, Falwell aponta que os próprios negros não queriam a integração, posto que a tendência natural de escolas públicas não segregacionistas seria resultar em casamentos inter-raciais. Interpretando as questões raciais a partir de uma leitura literal e específica da Bíblia, Falwell alerta para os perigos de desobediência às ordens de Deus, subjugando a Constituição norte-americana aos escritos sagrados. Casais inter-raciais, portanto, seriam a vingança divina, resultando numa desagregação da sociedade norte-americana.

\footnotetext{
${ }^{11}$ A decisão Brown vs Board of Education, de 1954, alterou a interpretação da Suprema Corte com relação à $14^{\mathrm{a}}$ Emenda que na seção 1 determina que "Todas as pessoas nascidas ou naturalizadas nos Estados Unidos e sujeitas a sua jurisdição são cidadãos dos Estados Unidos e do Estado onde tiver residência. Nenhum Estado poderá fazer ou executar leis restringindo os privilégios ou as imunidades dos cidadãos dos Estados Unidos; nem poderá privar qualquer pessoa de sua vida, liberdade ou bens sem processo legal, ou negar a qualquer pessoa sob sua jurisdição a igual proteção das leis."
}

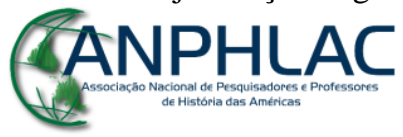

Revista Eletrônica da ANPHLAC, ISSN 1679-1061, №. 24, p. 253-280, Jan./Jun., 2018.

http://revista.anphlac.org.br 
"Se você não acredita, vá para as cidades do norte onde isto [integração] tem sido tentado. Em uma cidade do norte, um pastor meu amigo me disse que um casal ${ }^{12}$ de raças opostas vivem ao lado de sua igreja, como marido e mulher."13

Como aponta Winter (2012), o discurso segregacionista entre os pastores batistas era a norma naquele momento. Embora seja preciso apontar a exceção de Billy Graham que, em 1952, passou a defender a integração racial nas escolas batistas e retirou o muro que separava a seção dos brancos e dos negros em sua igreja.

Em meados dos anos 1960, a TRBC contava com quase 7 mil membros, e Jerry Falwell havia se tornado um líder religioso com bastante influência local e alguma penetração nacional. A TRBC havia se tornado uma Megachurch.

$$
* * *
$$

Como afirma Winters (2012), o termo megachurch não deve ser aplicado apenas tendo em mente o elevado número de fiéis. Esta se caracteriza por oferecer um elevado e diversificado número de serviços para o público, como clubes para solteiros, mães e jovens; tratamento para alcoólatras e drogados; pré-escola, escolas primárias, secundárias e até mesmo universidades. "A megachurch é uma espécie de vila organizada em torno da igreja, oferecendo alternativas às ofertas sociais, educacionais e culturais encontradas na cultura mais ampla” (WINTERS, 2012, p. 3).

A luta contra o alcoolismo tornou-se a principal bandeira de Jerry Falwell e, em 1963, a sua igreja adquiriu uma ilha nos arredores de Lynchburg por 50 mil dólares, iniciando a Elim Home for Alcoholics, uma espécie de oásis que pudesse servir de refúgio para a recuperação de alcoólatras, mantendo-se distantes das facilidades encontradas nas cidades.

Ao longo dos anos 1960, a TRBC inaugurou sua própria escola primária, a Lynchburg Christian Academy, expandindo a sua grade dois anos depois para se tornar também uma escola secundária. A construção de uma escola cristã por Jerry Falwell não foi um empreendimento singular em comparação a outras igrejas fundamentalistas. $\mathrm{O}$ movimento das escolas cristãs surgiu no sul dos Estados Unidos na virada dos anos

\footnotetext{
12 Apenas em 1967 a Suprema Corte negou aos estados ainda com leis segregacionistas (dentre eles a Virgínia) o direito de proibir o casamento inter-racial.

${ }^{13}$ FALWELL, Jerry. Integration or Segregation, 1958. Sermão. Arquivo pessoal: Susan Harding.
}

\section{GANPHLAC}

Revista Eletrônica da ANPHLAC, ISSN 1679-1061, №. 24, p. 253-280, Jan./Jun., 2018.

http://revista.anphlac.org.br 
1950 para os anos 1960 em contraposição às decisões da Suprema Corte que passaram a interferir na dinâmica das escolas públicas. Além da proibição da segregação racial de 1954, outras importantes decisões da Suprema Corte nos casos Engel v. Vitale, de 1962, e Abington School District v. Schempp, de 1963, resultaram conjuntamente na proibição da leitura da Bíblia e da oração em escolas públicas, impelindo os fundamentalistas cristãos e outros protestantes conservadores a construírem suas próprias instituições de ensino. Outro fator determinante foi o fato de que, aos olhos dos grupos religiosos mais conservadores, o currículo escolar estava se tornando cada vez mais secular e humanista, incluindo temas caros para esses setores da sociedade norte-americana, como a educação sexual. Novos livros didáticos, além de darem primazia à teoria darwinista, incorporaram o princípio do "values clarification" de John Dewey, que encorajava os estudantes a julgarem o mundo de maneira independente, livres de textos "canônicos" e até mesmo da influência de seus pais.

\section{$* * *$}

Segundo Winters (2012, p. 77), "não havia revolução sexual, rock, protestos contra a guerra do Vietnã no mundo de Falwell. Seu mundo ainda estava centrado em Lynchburg."

Embora nos anos 1960 Jerry Falwell estivesse empenhado em consolidar a TRBC, na prática, é incorreto afirmar que o pastor não tivesse interesse nas agitações sociais que percorriam os Estados Unidos naqueles anos. Em suas memórias, buscando justificar seu polêmico sermão Segregation or Integration, Which?, Falwell aponta o ambiente em que fora criado como determinante para o seu preconceito no período.

\footnotetext{
Eu estava isolado dos grandes centros populacionais urbanos. Eu cresci onde segregações eram assumidas por quase todos, brancos e negros. [...] Nós não sabíamos nada de motins, passeatas, ou decisão da Suprema Corte naqueles primeiros dias. (FALWELL, 1997, p. 301)
}

Vale ressaltar que nas cidades do Sul dos Estados Unidos assassinatos e linchamentos faziam parte do cotidiano das comunidades negras mesmo antes dos protestos dos anos 1960. Por outro lado, em sua autobiografia, Falwell afirma: "Nós

\section{GANPHLAC}

Revista Eletrônica da ANPHLAC, ISSN 1679-1061, №. 24, p. 253-280, Jan./Jun., 2018.

http://revista.anphlac.org.br 
sulistas não achávamos que as coisas estavam tão ruins. Mas nós estávamos errados. Poucos de nós perceberam como os negros tinham sofrido". (FALWELL, 1997, p. 304). De fato, o sermão "Ministres and Marches" 14 tornou Falwell uma das vozes religiosas centrais contra o movimento pelos direitos civis, posicionando-se contra a participação de pastores nas marchas e nas manifestações ocorridas no contexto da luta pelos direitos civis. Para muitos de seus biógrafos ${ }^{15}$ este sermão representa um alinhamento de Falwell ao pensamento pré-milenarista naquele momento, que prevê o retorno de Cristo antes do reino de mil anos. Esta visão induziria seus pastores à passividade política, posto que o principal objetivo não seria construir o reino de Deus na Terra antes do retorno de Cristo (visão pós-milenarista), mas salvar o maior número de almas individualmente.

Entretanto, como afirma Rocha,

na politização do fundamentalismo, o pré-milenarismo buscou se compatibilizar com o engajamento político através da luta contra os inimigos da fé. O pessimismo se transformou numa luta pelo ideal de sociedade cristã contra os inimigos secularizantes. [...] A mobilização pré-milenarista surge em momentos de crise social, econômica e política. (ROCHA, 2010, p. 219)

Ou seja, a tradição de não engajamento político pode ser rejeitada pelos prémilenaristas em momentos onde a salvação das almas dependesse de se posicionar publicamente contra o que considerassem inimigos do cristianismo. Neste sentido, embora o sermão de Falwell defenda a não politização dos pastores, reafirmando que estes foram chamados para salvar almas, o seu próprio discurso contraria esta ideia. Não deixa de ser revelador o fato de o sermão atacar diretamente o pastor Martin Luther King, associando-o indiretamente aos comunistas.

Segundo a Constituição dos Estados Unidos, todo americano tem o direito de 'pacificamente' peticionar ao governo reparações de injustiças. [...] A igreja recebeu qualquer comando de Deus para se envolver em passeatas, manifestações ou quaisquer outras ações, como muitos pastores e líderes de igrejas estão fazendo atualmente em nome das reformas dos direitos civis? [...] Eu questiono a sinceridade e as intenções não violentas de alguns líderes pelos direitos civis, como o Dr. Martin Luther King, o Sr. James Farmer ${ }^{16}$, e

\footnotetext{
${ }^{14}$ FALWELL, Jerry. Ministres and Marches. 1965. Sermão. Arquivo pessoal Susan Harding.

${ }^{15}$ Ver Harding (2000) e Winters (2012).

16 James Leonard Farmer, Jr. (1920-1999) foi um dos líderes do movimento pelos Direitos Civis norteamericanos. Ele foi um dos organizadores do Freedom Ride em 1961, que resultou no fim da segregação racial no transporte interestadual. Ainda em 1942, fundou o Comitê da Igualdade Racial (Committee of
}

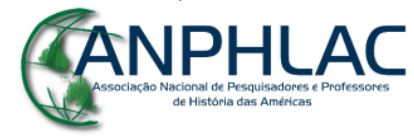

Revista Eletrônica da ANPHLAC, ISSN 1679-1061, №. 24, p. 253-280, Jan./Jun., 2018.

http://revista.anphlac.org.br 
outros, que são conhecidos por terem associações de esquerda. É muito óbvio que os comunistas, como fazem em todas as partes do mundo, estão se aproveitando dessa situação tensa em nosso país. ${ }^{17}$

Segregation or Integration, Which? e Ministers and Marches revelam um pastor dividido entre manter a pureza da doutrina pré-milenarista, focada na salvação individual, e dialogar com as questões políticas e sociais de seu tempo.

Em fins dos anos 1960 e início dos anos 1970, Jerry Falwell passou a viajar por todo o país divulgando suas ideias e, cada vez mais, estabelecendo contato com políticos e intelectuais conservadores. Aos poucos, outros “inimigos" seculares, como a liberdade sexual, os homossexuais, a pornografia e as feministas, somaram-se ao comunismo, como vetores da iminente destruição da sociedade norte-americana.

Se a relação entre os fundamentalistas cristãos e a arena política norte-americana era tensa, não só pelo estigma de atrasados e obscurantistas, mas também pelo discurso endógeno de "exílio", embora com diferentes graus de radicalidade, esta tensão não sobreviveria a Jerry Falwell.

\section{Jerry Falwell e a ascensão da Direita Cristã}

Segundo Schlensiger Jr. (1992), a partir de 1981, uma nova coalizão conservadora, capitaneada pelo então presidente eleito Ronald Reagan, foi muito além do âmbito econômico. Tratava-se, segundo seus adeptos, de um movimento popular, capaz de empolgar intelectuais, católicos, operários e as comunidades evangélicas. $\mathrm{Na}$ verdade, como afirma Foner (1999), a eleição de Reagan marcou o fim do predomínio da agenda econômica e social herdada do New Deal. Dentro desse contexto, percebemos a articulação de grupos religiosos conservadores (direta cristã) apresentando-se como uma força importante dentro do conjunto da Nova Direita.

Como afirma Finguerut,

a história da direita cristã é recente, tendo ganhado corpo apenas nos últimos

30 anos. Toda a chamada nova direita, onde a direita cristã se inclui como

Racial Equality), que mais tarde tornou-se o Congresso da Igualdade Racial (Congress of Racial Equality - CORE), uma organização que procurou realizar o fim da segregação racial nos Estados Unidos através da não violência. Farmer foi o primeiro líder da organização, servindo como presidente nacional 19421944.

${ }^{17}$ FALWELL, Jerry. Ministers and Marches. 1965. Sermão. Arquivo pessoal Susan Harding.

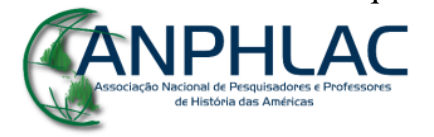

Revista Eletrônica da ANPHLAC, ISSN 1679-1061, №. 24, p. 253-280, Jan./Jun., 2018.

http://revista.anphlac.org.br 
também os neoconservadores e o conservadorismo, por eles revigorado, influenciaram o Partido Republicano e a própria sociedade americana. (FINGUERUT, 2009, p. 115-6)

Segundo Brinkley (1994), a ressurgência dos fundamentalistas cristãos na cena política norte-americana pegou muitos estudiosos de surpresa. Os objetivos principais deste grupo seriam combater o secularismo, o cientificismo e os valores sexuais liberais.

As memórias de Jerry Falwell revelam, na verdade, a busca por uma justificativa moral para que os fundamentalistas cristãos passassem a atuar diretamente na arena política institucional. Como afirma Winters (2012), Falwell não fez nada nos anos 1970 para questionar a decisão da Suprema Corte no caso Roe vs Wade, que, na prática, legalizou o aborto nos Estados Unidos, pondo em xeque o argumento moral.

Obviamente, os fundamentalistas sentiam-se atacados pelo Equal Rights Amendment (ERA), porém, discordâncias de cunho moral não eram novidades para este grupo. Neste sentido, podemos pensar que nos anos 1970 ocorreram outros fatores que, somados ao conjunto de leis progressistas, contribuíram para a mudança de perspectiva dos fundamentalistas, impelindo-os a atuarem através de novas práticas. Ou seja, manter-se "afastado" do mundo moderno não era mais suficiente. Era necessário intervir diretamente na agenda social e política do país.

Acreditamos que uma das formas de contribuir para compreensão dessa aliança, é analisar o processo que resultou no ativismo político do pastor fundamentalista Batista Jerry Falwell. Não no sentido de que Falwell tenha "criado" a Direita Cristã, mas pelo fato de ter tido participação importante na síntese das diferentes correntes conservadoras religiosas daquele período, incluindo católicos e judeus, através de sua liderança na organização política Moral Majority. Não se trata, obviamente, de pensarmos o pastor Jerry Falwell como um unificador das diferentes correntes conservadoras religiosas, mas sim como um negociador, articulando-as dentro de um projeto político definido que alcançou relativo grau de coesão, tornando-se uma importante base eleitoral para o partido Republicano.

De fato, a Moral Majority não foi um projeto pessoal de Jerry Falwell. Em maio de 1979, um grupo de políticos conservadores visitaram Falwell em Lynchburg com o intuito de recrutá-lo para o projeto. Jerry Falwell, na verdade, era a segunda opção. A primeira, Pat Robertson, negou-se a assumir a liderança do novo grupo político.

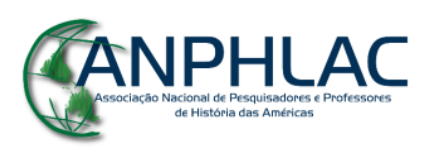

Revista Eletrônica da ANPHLAC, ISSN 1679-1061, №. 24, p. 253-280, Jan./Jun., 2018.

http://revista.anphlac.org.br 
O encontro foi organizado por Robert Billing, que anteriormente havia dirigido a National Christian Action Coalition. Fizeram parte das conversas ainda Ed McAteer, líder da Religious Roundtable, e os intelectuais conservadores e estrategistas políticos, Howard Phillips e Paul Weyrich. Na verdade, Falwell, no primeiro momento, não se sentiu confortável em sintetizar política e religião, repetindo a postura de Pat Robertson. Entretanto, acabou sendo convencido por Weyrich, após analisar uma pesquisa nacional onde a maioria dos eleitores via positivamente tal combinação. (WINTERS, 2012)

De fato, como afirma Hale (2011), em meados nos anos 1970, Falwell já dava claros sinais, através de sermões, de que estava disposto a intervir politicamente. Ou seja, o convite para liderar a Moral Majority não se deveu apenas a sua popularidade, mas também a uma predisposição anterior.

Fundada em 06 de junho de 1979, apenas um mês após a primeira reunião, o que sugere que já havia uma estrutura prévia alinhavada, a Moral Majority se definiu como uma instituição pró-família tradicional, pró-vida e pró-Israel, colocando-se publicamente contra o casamento gay, o aborto e o divórcio. Alguns analistas apontam que dois terços dos cristãos brancos sulistas que votaram em Ronald Reagan nas eleições de 1980 tinham ligações com a Moral Majority. (DIGGINS, 2007)

Embora seus integrantes não fossem necessariamente todos fundamentalistas cristãos, os membros da Moral Majority tinham uma agenda moral e social convergente. Acreditavam que a verdadeira "América" era conservadora e cristã, e que naquele momento era necessário defendê-la, pois estava sendo desfigurada por setores do governo federal e da mídia norte-americana, que impunham práticas e hábitos seculares e humanistas. (SMOLLA, 1988)

Jerry Falwell foi duramente criticado por outros líderes cristãos conservadores, como o pastor Billy Graham, por opinar através de seus sermões em assuntos políticos que não envolviam diretamente uma agenda moral religiosa. Ou seja, mesmo entre importantes figuras do conservadorismo religioso, a recém associação de Jerry Falwell entre política e religião, através da ação institucional, era polêmica.

Entretanto, para entendermos a tomada de decisão de Jerry Falwell em entrar diretamente na arena política, alterando uma perspectiva comum aos pastores fundamentalistas de manter distância do debate político pela via institucional, faz-se necessário conjugar dois fenômenos sociais que foram se constituindo em paralelo: as

\section{GANPHLAC}


leis progressistas advindas dos movimentos pelos direitos civis e a expansão econômica do Sunbelt.

Poderíamos citar como importantes leis progressistas, consideradas como um avanço do secularismo nos Estados Unidos pelos fundamentalistas, as decisões da Suprema Corte no caso Brown vs. Board of Education, em 1954, e no caso Abington School District vs. Schempp, em 1963, quando foram declarados inconstitucionais, respectivamente, a segregação racial e a oração em escolas públicas feita por professores em horário escolar ${ }^{18}$, além da legalização do aborto em 1973.

Embora estas leis tenham gerado alguma repercussão negativa entre os fundamentalistas cristãos, o fato de possuírem escolas religiosas particulares suavizava tais decisões, criando "ilhas" que se opunham, na teoria, ao avanço secularista.

Como afirma Hale,

\begin{abstract}
O sucesso do movimento pelos direitos civis em construir um sistema de integração nas escolas do sul na segunda metade dos anos sessenta e início dos setenta estendeu a sua [dos fundamentalistas] indignação e alimentou o movimento para a construção de academias privadas como a Lynchburg Christian Academy. Mas, ao final dos anos setenta, essas escolas também pareciam ameaçadas. (HALE, 2011, p. 265)
\end{abstract}

Entre 1970 e 1978, novas leis buscaram interferir nas escolas privadas de cunho religioso, tocando em temas importantes para os fundamentalistas, como a isenção de impostos e a proibição de segregação racial. Como afirma Devins (1983), durante muito tempo, as escolas cristãs privadas, algumas delas com subsídios do estado, foram utilizadas para contornar as leis progressistas citadas acima.

Entretanto, em 1970, o governo federal, através da Internal Revenue Service (IRS), proibiu a isenção fiscal para escolas privadas que impusessem algum tipo de discriminação racial ao corpo discente. Em 1975, a IRS implementou uma regra adicional, obrigando as escolas particulares a divulgarem suas políticas não discriminatórias. Em 21 de agosto de 1978, a IRS foi mais além, e passou a considerar como discriminatórias, as escolas que possuíssem um número pequeno de minorias étnicas entre seus alunos.

\footnotetext{
${ }^{18}$ Para saber mais sobre as disputas entre a Suprema Corte e as Escolas Privadas Cristãs, ver DEVINS, Neal. State Regulation of Christian Schools. (in) William \& Mary Law School Scholarship Repository, 1983. Disponível em: http://scholarship.law.wm.edu/cgi/viewcontent.cgi?article=1456\&context=facpubs Acesso em: 13 out. 2013.
}

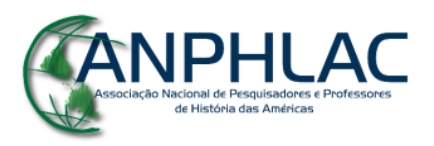

Revista Eletrônica da ANPHLAC, ISSN 1679-1061, №. 24, p. 253-280, Jan./Jun., 2018.

http://revista.anphlac.org.br 
O caso mais controverso ocorreu no embate entre a IRS e a Bob Jones University, localizada em Greenville, Carolina do Sul. Embora não fosse filiada a nenhuma denominação religiosa, a universidade seguia a doutrina fundamentalista cristã, impondo diversas regras morais e de conduta aos seus estudantes. Dentre elas, estava a proibição de relacionamentos inter-raciais. Como forma de garantir a separação étnica, a universidade instituiu uma regra específica para a admissão de negros: estes deveriam ser casados.

Em 1971, a Bob Jones University, em resposta à determinação da IRS do ano anterior, solicitou que não fosse mais incluída no programa de isenção fiscal, buscando assim continuar com suas práticas segregacionistas. Em 1976, a IRS revogou o benefício da Bob Jones University e solicitou que esta devolvesse retroativamente aos cofres públicos os impostos não recolhidos entre 1971 e 1976. A Bob Jones entrou com ação na justiça contra a IRS, perdendo o processo na Suprema Corte, em 1981.

Embora mais tarde, já durante a administração Reagan, as determinações da IRS tenham sofrido uma nova interpretação, suavizando as regras, este fato causou grande comoção entre as denominações fundamentalistas que possuíam escolas e universidades privadas.

Como afirma Hale (2011), as ações da IRS assustaram os fundamentalistas. Questões antigas, como a legalização do álcool ou o ensino do evolucionismo, pareceram pequenas diante da intervenção direta no interior das instituições educacionais, consideradas um bunker fundamentalista diante das transformações do mundo secular.

Neste sentido, embora a lei Roe vs Wade de 1973 tenha servido, posteriormente, de retórica moral para justificar a entrada na arena política da Direita Cristã, foi apenas durante a intervenção governamental num terreno considerado sagrado pelos fundamentalistas, suas instituições educacionais privadas, que eles se viram impelidos a debater no espaço público sua agenda política. Através da Moral Majority, Jerry Falwell, embora tenha criticado as tendências discriminatórias da Bob Jones University, criticou veementemente a intervenção do governo federal em entidades privadas.

A crítica fundamentalista ao intervencionismo do governo em suas escolas privadas encontrou eco no pensamento neoconservador, que também se opunha ao excesso de poder do governo federal. Embora a crítica religiosa e política tivessem

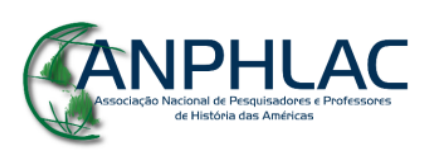

Revista Eletrônica da ANPHLAC, ISSN 1679-1061, №. 24, p. 253-280, Jan./Jun., 2018.

http://revista.anphlac.org.br 
origens diferentes, moral e econômica, respectivamente, os fatores econômicos também assombravam os fundamentalistas, posto que a intervenção governamental geraria mais custos, e, como vimos anteriormente, os aspectos religiosos e morais não eram negligenciados pelos neoconservadores.

Importante apontar que em seu livro Listen, America!: The conservative blueprint for America's moral rebirth ${ }^{19}$, publicado em 1980, Jerry Falwell tenha dedicado todo o primeiro capítulo a discutir os aspectos econômicos dos Estados Unidos e a Guerra Fria. No primeiro capítulo, intitulado Liberty - Will we keep it?, Falwell critica a política do welfare state e faz uma importante defesa dos projetos econômicos de Margaret Thatcher na Grã-Bretanha.

\begin{abstract}
Até os primeiros dias deste século foi amplamente reconhecido que igrejas e outras instituições privadas tinham a responsabilidade principal, não apenas com relação à educação, mas também com os cuidados de saúde e de caridade. O caminho para derrotar o assistencialismo na América é, para aqueles que desejam ver a lei de Deus restaurada no nosso país, ofertar [doações] totalmente a organizações que removam do governo as tarefas que são tratadas mais apropriadamente por instituições religiosas e privadas. [...] A primeira-ministra Margaret Thatcher está fazendo movimentos ousados para restaurar a Grã-Bretanha. Ela afirmou que o socialismo aumenta o poder do Estado e que este aumento de poder não produz nem riqueza, nem mais liberdade, mas o inverso." (FALWELL, 1980, p. 11; 24)
\end{abstract}

Temas como família, homossexualidade, pornografia e educação, aparecem apenas no segundo capítulo, intitulado Morality - The Deciding Factor. Neste sentido, Falwell demonstra como a retórica fundamentalista cristã, majoritariamente direcionada para a preservação de valores morais tradicionais, incorporou os pressupostos do neoliberalismo. As teorias neoliberais de defesa do estado mínimo e da livre empresa passaram a encontrar justificativas em passagens bíblicas, de acordo com a interpretação da Direita Cristã. Citando o $3^{\circ}$ capítulo do livro II Tessalonicenses, Falwell encontra nas palavras de Paulo de Tarso a justificativa para atacar os programas assistencialistas do governo norte-americano:

Intimando-vos irmãos, em nome de nosso senhor Jesus Cristo, que eviteis a convivência de todo irmão que leve vida ociosa e contrária à tradição que de nós tendes recebido. Sabeis perfeitamente o que deveis fazer para nos imitar. Não temos vivido entre vós desregradamente, nem temos comido de graça o pão de ninguém. Mas, com trabalho e fadiga, labutamos noite e dia, para não

${ }^{19}$ Grifos nossos.

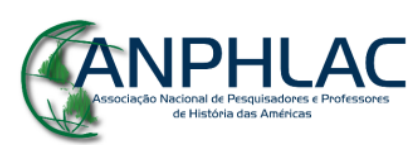

Revista Eletrônica da ANPHLAC, ISSN 1679-1061, №. 24, p. 253-280, Jan./Jun., 2018.

http://revista.anphlac.org.br 
sermos pesados a nenhum de vós. Não porque não tivéssemos poder para isso, mas foi para vos oferecer em nós mesmos um exemplo a imitar. Aliás, quando estávamos convosco, dizíamos formalmente: Quem não quiser trabalhar não tem o direito de comer. Entretanto, soubemos que entre vós há alguns desordeiros, que não trabalham, e são intrometidos. A esses indivíduos ordenamos e exortamos a que se dediquem tranquilamente ao trabalho para merecerem ganhar o que comer. Vós, irmãos, não vos canseis de fazer o bem.

Falwell complementa esta passagem bíblica afirmando: "quando o governo se preocupa com seu povo, por que seu povo deveria se preocupar consigo mesmo?" (FALWELL, 1980, p. 64)

Após tratar do que considera os pecados intrínsecos dos Estados Unidos, Falwell volta a sua atenção para o perigo externo: a União Soviética e o comunismo. Para o pastor, os norte-americanos estavam apáticos diante do comunismo, ignorando as ameaças vindas de Moscou e, principalmente, esquecendo os missionários norteamericanos que perderam suas vidas fundando hospitais e levando a palavra de Jesus para regiões de conflito, como a Indochina. Acreditando ter descoberto o modus operandi soviético, Falwell defendeu maiores investimentos na indústria bélica norteamericana, pois, segundo o pastor, a URSS, antes de invadir um país, aguardava o seu enfraquecimento militar e o aumento de sua corrupção moral.

Jerry Falwell era adepto da Teoria do Dominó, e passou a denunciar publicamente a invasão e expansão comunista na América Latina. Após a revolução Sandinista na Nicarágua em 1978, capitaneada pela Frente Sandinista de Libertação Nacional (FSLN), o governo Reagan passou a financiar os grupos contrarrevolucionários, denominados "Contras". Entre as alas conservadores norteamericanas havia o medo da influência soviética na América Latina e Caribe.

Como afirma Winters (2012), Falwell foi escolhido como porta voz do governo para denunciar o avanço do comunismo na América Central, e dessa forma, justificar a intervenção militar dos Estados Unidos. O pastor batista então pediu "permissão" ao presidente Ronald Reagan para gravar um documentário com os refugiados nicaraguenses em El Salvador. Em setembro de 1983, Falwell e sua equipe viajaram para aquele país em seu avião particular. O mais interessante é que Falwell não permaneceu nem 8 horas em solo salvadorenho, visitou apenas 1 dos 89 campos conhecidos de refugiados, mas retornou aos Estados Unidos com um "raio X completo da iminente expansão comunista na região", exortando o Congresso norte-americano a

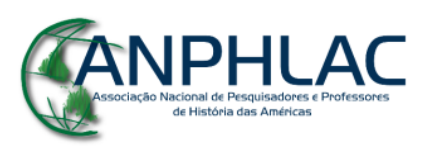

Revista Eletrônica da ANPHLAC, ISSN 1679-1061, №. 24, p. 253-280, Jan./Jun., 2018.

http://revista.anphlac.org.br 
permitir que o presidente Reagan enviasse mais armas ao exército salvadorenho e continuasse a ajudar os Contras na Nicarágua.

Entretanto, a operação retórica de Falwell em vincular passagens bíblicas com os valores do liberalismo econômico e com o incremento da indústria bélica norteamericana, para fazer frente à ameaça comunista, não pode ser atribuída simplesmente a um acordo tácito com os neoconservadores. Jerry Falwell expandiu a sua Igreja justamente numa região onde os valores neoliberais e a indústria bélica floresciam. Sua cidade natal, Lynchburg, sofreu uma importante modificação em sua estrutura demográfica e econômica a partir dos anos 1950, com a chegada de duas poderosas indústrias à região. Em 1955, a Babcok \& Wilcox (B\&W) e a General Eletric (GE) instalaram na cidade centros de produção de reatores nucleares e rádio. A abertura de novas vagas de emprego e o crescimento econômico da região alterou o perfil social de Lynchburg. A modesta cidade rural na primeira metade do século XX transformou-se num centro econômico vibrante, com a expansão dos subúrbios, lojas de departamento e bancos.

Como afirma Williams (2010), os novos trabalhadores brancos que chegaram à cidade em busca de empregos, desenvolveram um forte sentimento de fé na industrialização, na possibilidade de crescimento econômico através do trabalho árduo e no comprometimento com os gastos nacionais cada vez mais elevados na produção de armas e tecnologias, visando garantir a defesa nacional no contexto da Guerra Fria.

Neste sentido, o público de Jerry Falwell também mudou, passando de uma maioria branca, pobre e segregacionistas, para uma maioria formada por brancos da classe média com um pensamento social diferente. O pastor começou a se distanciar da política segregacionista e aproximar-se do conservadorismo da Sunbelt, que estava mais alinhado com os interesses do partido Republicano de sua cidade.

Esta percepção de Falwell gerou um grande aumento da receita da TRBC, passando de 5 milhões anuais em 1973, para 50 milhões em 1976. Na prática, a suavização do discurso segregacionista de Falwell, contribuiu para uma abertura maior de diálogo com outras denominações evangélicas, e mesmo com outras religiões, como o catolicismo e o judaísmo, enquanto se alinhavam cada vez mais ao partido Republicano. Em 1976, enquanto vários pastores batistas do sul dos Estados Unidos

\section{GANPHLAC}


apoiaram a candidatura à presidência do democrata Jimmy Carter, Falwell apoiou a candidatura do então presidente republicano Gerald Ford.

Jerry Falwell iniciou assim uma aliança com o partido Republicano que alcançaria seu auge durante as duas administrações de Ronald Reagan nos anos 1980, quando se tornou o líder da Moral Majority e um dos personagens religiosos mais proeminente dos Estados Unidos no final do século XX.

\section{Conclusão}

A análise da autobiografia de Jerry Falwell nos permite compreender alguns dos principais fatores que contribuíram para a ascensão da Direita Cristã nos Estados Unidos no último quarto do século XX.

Embora fatores morais sejam elencados como o motivo principal para o início do ativismo político de pastores fundamentalistas, torna-se evidente que fatores econômicos, alinhando-se com o projeto neoliberal, foram decisivos para o apoio da Direita Cristã ao partido Republicano.

Vale ressaltar que no contexto de publicação da obra Jerry Falwell: an autobiography, os Estados Unidos estavam sob administração Democrata ${ }^{20}$, sendo, portanto, fundamental reforçar o apoio religioso conversador ao partido Republicano.

Embora o apoio de Falwell ao governo Reagan não tenha revertido vários dos avanços considerados progressistas, é correto afirmar que, no fim dos anos 1980, o partido Republicano tornou-se o espaço privilegiado para a atuação da Direita Cristã.

Vale ressaltar que nessa aparente tensão dos Fundamentalistas entre se isolar do mundo secular e interferir diretamente na arena política, a estratégia, como aponta Golderberg (2007), já foi traçada: construir, através da educação em casa, os futuros quadros que ocuparão postos chaves da república, como ministros do Supremo, congressistas e até mesmo presidentes, de modo a lograr instituir nos Estados Unidos uma agenda moral e econômica mais conservadora, e reverter os avanços progressistas dos últimos 50 anos.

É impossível prever se terão sucesso, mas com a ascensão do Tea Party e a recente eleição de Donaldo Trump, torna-se relevante conhecer a história da aliança

20 Primeiro mandato de Bill Clinton, presidente dos Estados Unidos entre 1993-2001.

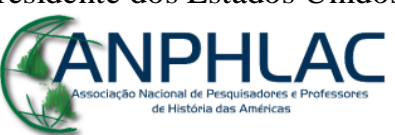

Revista Eletrônica da ANPHLAC, ISSN 1679-1061, №. 24, p. 253-280, Jan./Jun., 2018.

http://revista.anphlac.org.br 
entre o partido Republicano e a Direita Cristã; sendo o pastor Jerry Falwell um personagem fundamental nessa empreitada.

\section{Referências Bibliográficas}

AURELL, Jaume. Textos autobiográficos como fontes historiográficas: relendo Fernand Braudel e Anne Kriegel. História (São Paulo) v. 33, nº 1, p. 340-364, jan./jun. 2014.

BRINKLEY, Alan. The Problem of American Conservatism. The American Historical Review. Vol 99, n², 1994.

DEVINS, Neal. State Regulation of Christian Schools. William \& Mary Law School Scholarship Repository, 1983.

DIGGINS, John Patrick. Ronald Reagan: fate, freedom, and the making of history. New York/London: W. W. Norton, 2007.

FALWELL, Jerry. Listen, America. New York: Doubleday, 1980.

FALWELL, Jerry. An Autobiography: The Inside Story. Lynchburg: Liberty House Publishers, 1997.

FALWELL, Macel. Jerry Falwell: his life and legacy. New York: Howard Books, 2008.

FINGUERUT, Ariel. Formação, crescimento e apogeu da direita cristã nos Estados Unidos. In: SILVA, Carlos Eduardo Lins da (Org.). Uma Nação com alma de Igreja: religiosidade e políticas públicas nos EUA. São Paulo: Paz e Terra, 2009.

GOLDBERG, Michelle. Kingdom Coming. New York, London: W.W. Norton, 2007.

HANGEN, Tona J. Redeeming the dial: radio, religion and popular culture in America. Chapell Hill: University of North Carolina Press, 2002.

HALE, Grace Elizabeth. A Nation of Outsiders: How the white middle class fell in love with rebellion in postwar America. Oxford University Press: New York, 2011.

JUNQUEIRA, Mary A. Estados Unidos: A consolidação da nação. São Paulo: Contexto, 2001.

MARDSEN, George M. Fundamentalism and American Culture: the shape of twentieth-century evangelicalism 1870-1925. Oxford, New York, Toronto: Oxford University Press, 1980.

MARDSEN, George M. Religion and American Culture. Belmont, CA: Thompson Wadsworth, 2001.

PURDY, Sean. O Século Americano. KARNAL, Leandro et al. História dos Estados Unidos: das origens ao século XXI. São Paulo: Contexto, 2007.

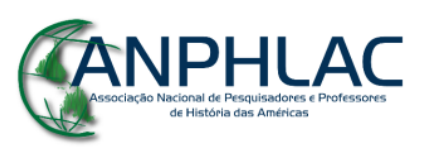

Revista Eletrônica da ANPHLAC, ISSN 1679-1061, №. 24, p. 253-280, Jan./Jun., 2018.

http://revista.anphlac.org.br 
ROCHA, Daniel. Os Fundamentos de um Reino Milenar: expectativas milenaristas e engajamento político na história do fundamentalismo religioso norte-americano. Fronteiras. Dourados, MS, v. 12, $\mathrm{n}^{\mathrm{O}} 1$, jan./jun. 2010.

ROOF, Wade Clark; CARON, Nathalie. Shifting Boundaries: religion and the United States: 1960 to the present. In: BIGSBY, Christopher. The Cambridge Companion to Modern American Culture. London: Cambridge University Press, 2006.

SCHLESINGER JR., Arthur M. Os Ciclos da História Americana. Rio de Janeiro: Civilização Brasileira, 1992.

SMOLLA, Rodney A. Jerry Falwell v. Larry Flynt: the first amendment on trial. New York: St. Martin Press, 1988.

WILLIAMS, Daniel K. Jerry Falwell's Sunbelt Politics: The regional origins of the Moral Majority. The Journal of Policy History. Vol. 22, $\mathrm{n}^{\circ}$ 2, 2010.

\section{GANPHLAC}

